\title{
Removal of Boron from Metallurgical-grade Silicon by Applying the Plasma Treatment
}

\author{
Kichiya SUZUKI, Tomonori KUMAGAI) and Nobuo SANO
}

Department of Metallurgy, Faculty of Engineering, The University of Tokyo, Hongo, Bunkyo-ku, Tokyo, 113 Japan.

1) Formerly Faculty of Engineering, The University of Tokyo. Now at Recruit Co., Ltd., Chuuo-ku, Tokyo, Japan.

(Received on November 7, 1991; accepted in final form on January 24, 1992)

\begin{abstract}
The removal of boron from metallurgical-grade silicon was investigated by applying an $\mathrm{Ar} / \mathrm{H}_{2} \mathrm{O}$ plasma treatment to develop a new production technique for low cost solar-grade silicon (SOG-Si).

The concentration of boron in MG-Si decreased from 35.7 to $0.4 \mathrm{ppmw}$, satisfying the requirement for SOG-Si, using $\mathrm{Ar}+1.24 \mathrm{vol} \% \mathrm{H}_{2} \mathrm{O}$ plasma gas for $25 \mathrm{~min}$ of melting time. It has been demonstrated that the overall rate of elimination of boron is controlled by the diffusion of boron in silicon melts. The removal of boron is affected by the kind of plasma operating gas with the highest elimination rate of boron by $\mathrm{Ar} / \mathrm{H}_{2} \mathrm{O}$ plasma. The experimental findings support that boron in silicon reacts with oxygen in gas only at the plasma-impinging area.

It may be said that only this technique has the possibility to lower boron content of silicon down to the required $0.1 \mathrm{ppm}$ for $S O G$.
\end{abstract}

KEY WORDS: silicon; solar cell; refining; thermal plasma; boron.

\section{Introduction}

The crystalline silicon solar cell has drawn strong attention as a candidate for supplementary power generation in the near future and its importance is rapidly growing for conservation of earthly environment at the moment.

A solar cell for power generation has been produced using expensive off-grade electronic silicon (SEG-Si). Therefore, the cost of electricity by the present solar cell is very high and it cannot compete with existing large scale commercial power. One of the prerequisites for large-scale photovoltaic energy conversion using silicon solar cell is a substantial reduction in its manufacturing cost.

The ultimate purpose of this study is to develop a process that enables us to produce inexpensive solar grade silicon (SOG-Si). Many different approaches ${ }^{1)}$ have been proposed in the area of low-cost silicon feedstock processing. Among them, a processing route via refining of metallurgical grade silicon (MG-Si) seems to offer the best chance of producing SOG-Si at low cost. A technical problem in this processing is to effectively remove boron and phosphorus from MG-Si, contents of which are in the range from 20 to $40 \mathrm{ppmw}$. These impurities are doping elements for SOG-Si, so that their concentrations are required to be controlled below 1 ppmw. However, both elements are very difficult to be removed by using a directional solidification or zone melting technique because their segregation coefficients are close to unity. The authors have carried out a series of experiments for removing boron and phosphorus by applying vacuum, flux, and plasma treatments. ${ }^{2,3}$ The behavior of boron during $\mathrm{Ar} / \mathrm{H}_{2} \mathrm{O}$ plasma treatment is reported in the present study.

\section{Experimental Principle}

The affinity of boron toward oxygen is as high as that of silicon. Two practical methods are considered for removing boron from $\mathrm{MG}-\mathrm{Si}$, one is a flux treatment and the other is an oxidizing plasma treatment. In the flux treatment, boron is oxidized to form boron oxide, $\mathrm{B}_{2} \mathrm{O}_{3}$, which is stable in basic fluxes such as silicates of alkaline earth metals. Thus the boron in MG-Si is expected to be oxidized and transferred into basic fluxes. Experimental results in connection with the flux treatment have been reported elsewhere by the authors. ${ }^{3)}$ As described there, boron content of $\mathrm{MG}-\mathrm{Si}$ after this treatment will not be low enough, unless a very large amount of flux is used.

In the plasma treatment, gaseous boron oxides such as $\mathrm{BO}, \mathrm{B}_{2} \mathrm{O}, \mathrm{B}_{2} \mathrm{O}_{3}$, etc. are expected to form at temperatures higher than $2300 \mathrm{~K}$. Of these boron oxides, $\mathrm{BO}$ has a relatively high vapor pressure. For example, the vapor pressure of $\mathrm{BO}$ is estimated to be $74 \mathrm{~Pa}$ for an activity of boron in silicon of $10^{-4}$ under the oxygen partial pressure controlled by $\mathrm{Si}(\mathrm{l})+\mathrm{O}_{2}(\mathrm{~g})=\mathrm{SiO}_{2}(\mathrm{l})$ at $2273 \mathrm{~K}$, while those of $\mathrm{BO}_{2}$ and $\mathrm{B}_{2} \mathrm{O}_{3}$ are 0.15 and $0.056 \mathrm{~Pa}$, respectively. Therefore, boron may be removed as BO from silicon melts under oxidizing plasma conditions. 
As described earlier, the authors have investigated the removal of boron using an $\mathrm{Ar} / \mathrm{O}_{2}$ or $\mathrm{Ar} / \mathrm{CO}_{2}$ plasma ${ }^{2)}$ and have found that the oxidizing plasma treatment is more effective than the flux treatment for removing boron. In the present study, the behavior of boron in an $\mathrm{Ar} / \mathrm{H}_{2} \mathrm{O}$ plasma has been investigated and compared with previous results by an $\mathrm{Ar} / \mathrm{O}_{2}$ or $\mathrm{Ar} / \mathrm{CO}_{2}$ plasma. The removal of boron in silicon by use of an $\mathrm{Ar}-\mathrm{H}_{3}-\mathrm{H}_{2} \mathrm{O}$ gas mixture has been reported by Theuerer $^{4)}$ for zone melting. Amouroux et al. ${ }^{5)}$ used an $\mathrm{Ar}-\mathrm{H}_{2}-\mathrm{O}_{2}$ gas mixture for high-frequency induction plasma and $\mathrm{Baba}$ et $a .^{6)}$ used an $\mathrm{Ar}-\mathrm{H}_{2} \mathrm{O}$ or $\mathrm{Ar}-\mathrm{He}-\mathrm{H}_{2} \mathrm{O}$ for a nontransfer type plasma with $600 \mathrm{~g}$ of silicon in a quartz crucible.

\section{Experimental}

\subsection{Equipments}

As shown in Fig. 1, the plasma furnace was equipped with a transfer type torch with $10 \mathrm{~kW}$ of maximum output. A weakly oxidizing plasma was prepared by the addition of wetted Ar to a main Ar carrier. The total flow rate was controlled to be $1.16 \times 10^{-4} \mathrm{~m}^{3} / \mathrm{s}$ throughout the present experiments.

The wetted Ar was prepared by passing Ar through a

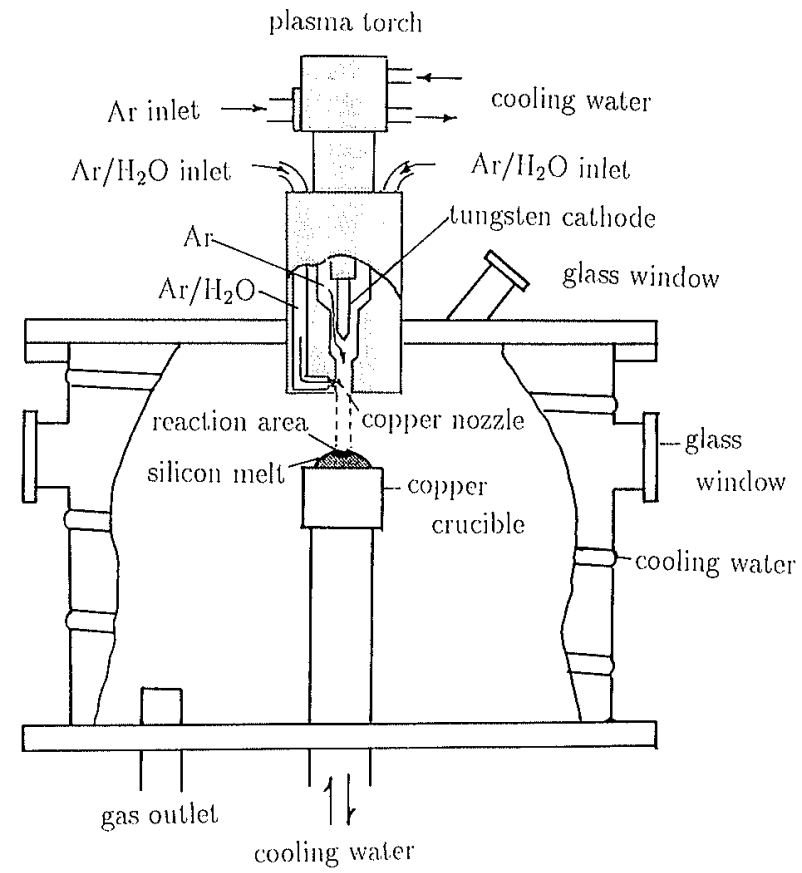

Fig. 1. Schematic representation of the plasma melting furnace.

Table 1. Manufacturer's analysis of MG-Si used in the present study.

\begin{tabular}{cc}
\hline Impurities & Content (ppmw) \\
\hline $\mathrm{C}$ & 60 \\
$\mathrm{~B}$ & $30-40$ \\
$\mathrm{Al}$ & $500-900$ \\
$\mathrm{Fe}$ & $260-400$ \\
$\mathrm{Ti}$ & 10 \\
$\mathrm{Cu}$ & 2 \\
$\mathrm{Ca}$ & 60 \\
\hline
\end{tabular}

stainless steel water bath, $70 \mathrm{~mm}$ i.d. and $280 \mathrm{~mm}$ in height. The percentage of $\mathrm{H}_{2} \mathrm{O}$ in the plasma gas was controlled by changing the flow rate of argon. The tubing between the bath and the torch was wound with a ribbon heater to prevent condensation of water vapor.

\subsection{Procedures}

A flaky MG-Si containing 35.7 ppmw of boron was mainly used and in some cases other samples having 5 and $15 \mathrm{ppmw}$ of boron were used. Table 1 shows the manufacturer's analysis of the sample.

Approximately $5.5 \mathrm{~g}$ of silicon were melted on a water-cooled copper disk with $28 \mathrm{~mm}$ in diameter. The boron elimination and silicon loss were investigated as a function of melting time under various conditions. After the sample was treated, it was turned over to repeat the same treatment to make sure of its homogeneity. Therefore, melting time is defined as the total time for treating the top and bottom parts of the sample. With this technique, the reproducibility of boron analysis was controlled to within $\pm 10 \%$. As shown in Table 2, the operating parameters are $\mathrm{H}_{2} \mathrm{O}$ concentration of the plasma gas, kind of oxidant, initial concentration of boron in silicon, and flux addition.

Analysis of boron was performed by inductively coupled plasma emission spectroscopy (ICP-ES).

\section{Results and Discussion}

\subsection{Effects of $\mathrm{H}_{2} \mathrm{O}$ Concentration of the Plasma Operating Gas on the Rate of Boron Elimination and Silicon Loss}

The results of boron elimination and silicon loss after 10 min are presented as a function of $\mathrm{H}_{2} \mathrm{O}$ vol $\%$ of the operating gas in Fig. 2. As is seen in the figure, the rate

Table 2. Experimental parameters and their ranges of variation.

\begin{tabular}{|c|c|}
\hline Parameter & \\
\hline Boron content of silicon & $5,15,35.7 \mathrm{ppmw}$ \\
\hline Experimental time & $4-25 \mathrm{~min}$ \\
\hline Plasma gas composition & $\mathrm{Ar}+\mathrm{H}_{2} \mathrm{O}\left(\mathrm{H}_{2} \mathrm{O}: 0-14.6\right.$ vol\% $\left.\%\right)$ \\
\hline Addition of fiux & $\begin{array}{c}\mathrm{Ar}+0.44 \mathrm{vol} \% \mathrm{H}_{2} \mathrm{O}+0.44 \mathrm{vol}^{\circ} \% \mathrm{CO}_{2} \\
\mathrm{CaF}_{2}(10-30 \text { mass } \%)\end{array}$ \\
\hline
\end{tabular}

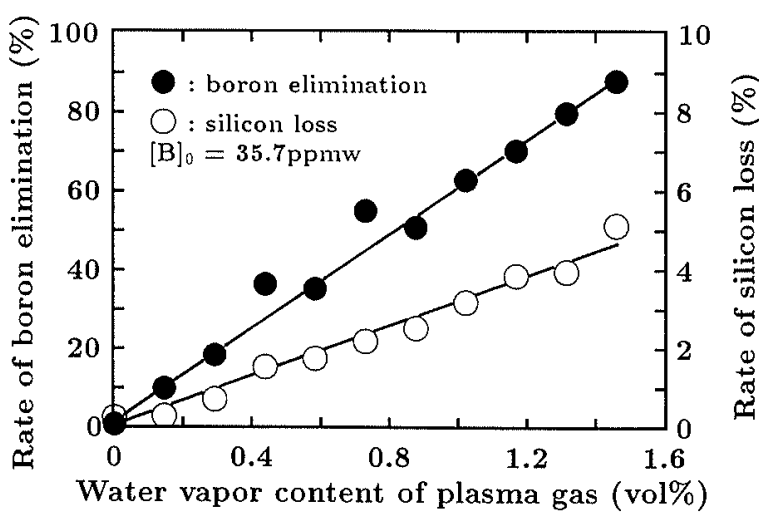

Fig. 2. Dependence of the rate of boron elimination and silicon loss on the $\mathrm{H}_{2} \mathrm{O}$ content of plasma gas in $10 \mathrm{~min}$ of melting time. 


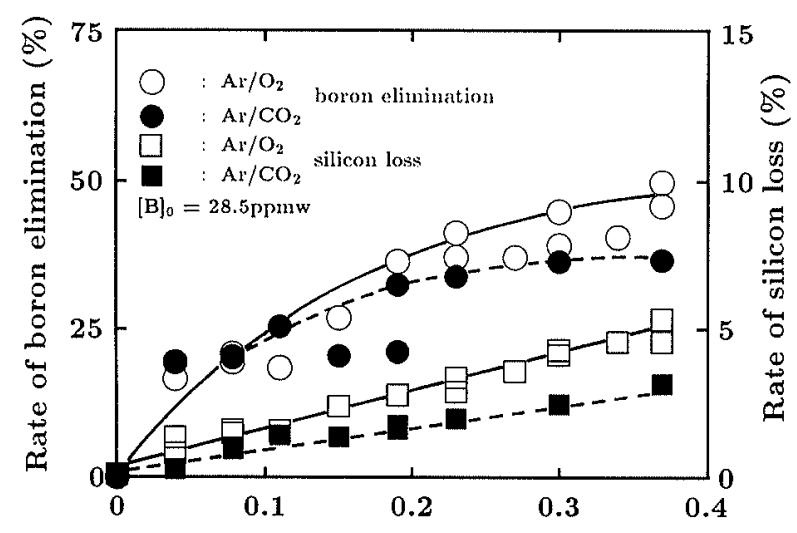

$\mathrm{O}_{2}$ and $\mathrm{CO}_{2}$ content of plasma gas ( $\mathrm{vol} \%$ )

Fig. 3. Dependence of the rate of boron elimination and silicon loss on $\mathrm{O}_{2}$ and $\mathrm{CO}_{2}$ content of plasma gas in $10 \mathrm{~min}$ of melting time.

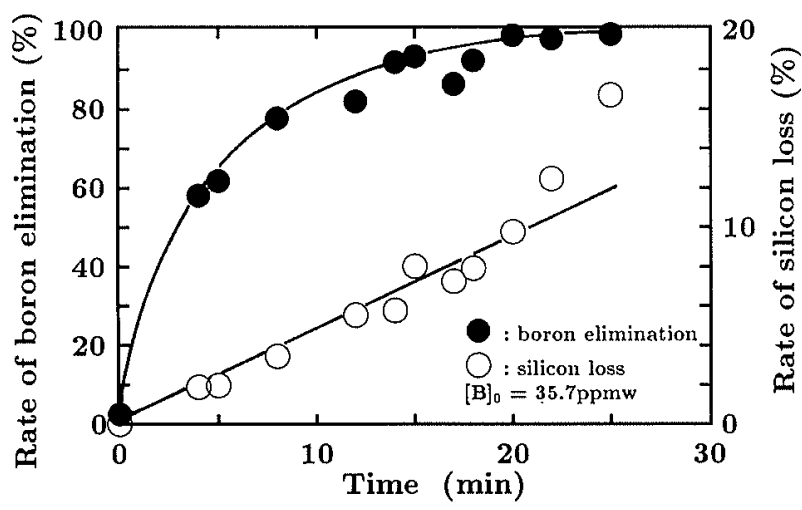

Fig. 4. Rate of boron elimination and silicon loss with $\mathrm{Ar}+1.24 \mathrm{vol} \% \mathrm{H}_{2} \mathrm{O}$ plasma gas as a function of time.

of boron elimination $\left(\eta_{\mathrm{B}}\right)$ and silicon loss $\left(\delta_{\mathrm{Si}}\right)$ increased linearly with increasing the concentration of $\mathrm{H}_{2} \mathrm{O}$. Figure 3 shows the previous results with an $\mathrm{Ar} / \mathrm{O}_{2}$ or $\mathrm{Ar} / \mathrm{CO}_{2}$ plasma for comparison. In both cases of $\mathrm{Ar} / \mathrm{O}_{2}$ and $\mathrm{Ar} / \mathrm{CO}_{2}, \eta_{\mathrm{B}}$ also increased with increasing the concentration of $\mathrm{O}_{2}$ or $\mathrm{CO}_{2}$ at the beginning of melting, but it levels off beyond about $0.2 \mathrm{vol} \%$ of oxidizing gas concentration. These differences in the trend of $\eta_{\mathrm{B}}$ between $\mathrm{Ar} / \mathrm{H}_{2} \mathrm{O}$ and $\mathrm{Ar} / \mathrm{O}_{2}$ or $\mathrm{Ar} / \mathrm{CO}_{2}$ plasmas are caused by whether or not an $\mathrm{SiO}_{2}$ film is formed on the surface of silicon melts during melting. The formation of $\mathrm{SiO}_{2}$ film was observed on the surface in both cases of $\mathrm{Ar} / \mathrm{O}_{2}$ and $\mathrm{Ar} / \mathrm{CO}_{2}$ plasmas, but not in the case of $\mathrm{Ar} / \mathrm{H}_{2} \mathrm{O}$ plasma. Thus, water vapor in the plasma gas suppresses the formation of solid oxide of silicon by forming only gaseous $\mathrm{SiO}$, resulting in enhancement of the gaseous removal of boron.

\subsection{Kinetics of the Removal of Boron}

Figure 4 shows the change in boron concentration with time using an $\mathrm{Ar}+1.24 \mathrm{vol} \% \mathrm{H}_{2} \mathrm{O}$ plasma. It can be seen that $\eta_{\mathrm{B}}$ rapidly increases at the beginning of melting until about $15 \mathrm{~min}$ and then it levels off. The maximum elimination was $98.9 \%$ around at $25 \mathrm{~min}$ melting time, the final concentration of boron in silicon being $0.4 \mathrm{ppmw}$. This boron level is lower than that required for SOG-Si.

In the previous study, ${ }^{2)}$ which was carried out with

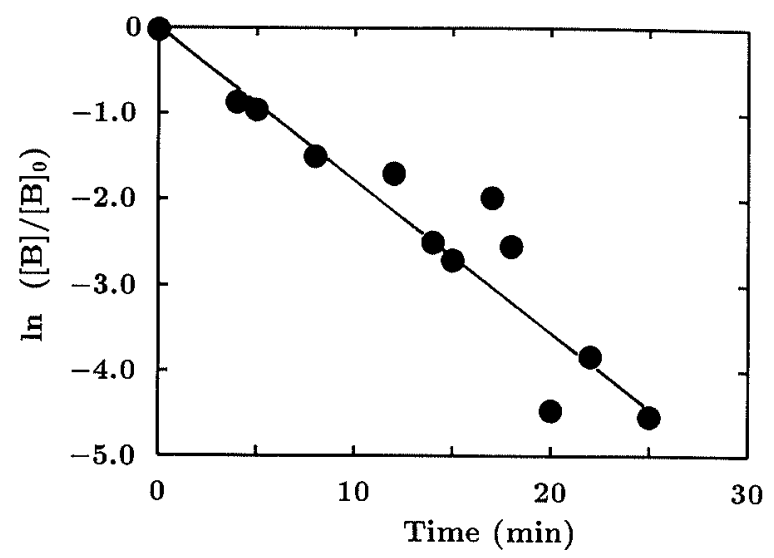

Fig. 5. Relation between $\ln \left([\mathrm{B}] /[\mathrm{B}]_{0}\right)$ and melting time for boron elimination with $\mathrm{Ar}+1.24 \mathrm{vol}_{0} \mathrm{H}_{2} \mathrm{O}$ plasma gas.

MG-Si containing 28.5 ppmw of boron by using an $\mathrm{Ar}+0.7 \mathrm{vol} \% \mathrm{CO}_{2}$ plasma, the maximum elimination was about $90 \%$ at $30 \mathrm{~min}$ melting time and the final concentration of boron was about 4 ppmw. On the other hand, the rate of silicon loss was about $1.6 \% / \mathrm{min}$ in the previous study in contrast with $0.4 \% / \mathrm{min}$ in this case at the fixed oxygen content of the plasma gas. Obviously from this comparison, the $\mathrm{Ar} / \mathrm{H}_{2} \mathrm{O}$ plasma has certain advantages over the $\mathrm{Ar} / \mathrm{CO}_{2}$ or $\mathrm{Ar} / \mathrm{O}_{2}$ for removal of boron from silicon.

The rate equation for removing boron is expressed by Eq. (1) or (2), assuming the rate is controlled by the diffusion of boron from the bulk to the surface of the silicon melt.

$$
\begin{aligned}
& -\frac{d[\mathrm{~B}]}{d t}=k\left\{[\mathrm{~B}]-[\mathrm{B}]_{i}\right\} \\
& \ln \frac{\left\{[\mathrm{B}]-[\mathrm{B}]_{i}\right\}}{\left\{[\mathrm{B}]_{0}-[\mathrm{B}]_{i}\right\}}=-k t
\end{aligned}
$$

where, $k$ : apparent rate constant $\left(\mathrm{sec}^{-1}\right)$

[B]: concentration of boron at time, $t$ (ppmw)

$[\mathrm{B}]_{0}$ : initial concentration of boron (ppmw)

$[\mathrm{B}]_{i}$ : concentration of boron at surface of the melt (ppmw)

$i$ : time (sec).

Assuming that the concentration of boron at surface of the melt is nearly zero, Eq. (2) is rewritten by Eq. (3);

$$
\ln \left\{[\mathrm{B}] /[\mathrm{B}]_{0}\right\}=-k t
$$

Figure 5 shows the plot of $\ln \left\{[\mathrm{B}] /[\mathrm{B}]_{0}\right\}$ vs. $t$ on the basis of the data in Fig. 4. As is seen in this figure, a nearly linear relation between $\ln \left\{[\mathrm{B}] /[\mathrm{B}]_{0}\right\}$ and $t$ was obtained. From this result, the assumption made above seems to be valid in this case. The value of $k$ can be obtained from the slope in Fig. 5 and was calculated as $3 \times 10^{-3} \mathrm{sec}^{-1}$.

The apparent rate constant is expressed as follows;

$$
k=k_{m}(A / V)
$$

where, $k_{m}$ : mass transfer coefficient $(\mathrm{m} / \mathrm{s})$

$A$ : reaction area of silicon melt $\left(\mathrm{m}^{2}\right)$

$V$ : volume of silicon melt $\left(\mathrm{m}^{3}\right)$.

Accordingly, if the value of $A / V$ is known, the value of $k_{m}$ can be calculated from Eq. (4). The shape of the 
silicon melt was like a button, $2 \mathrm{~cm}$ in diameter and $1.5 \mathrm{~cm}$ in thickness at center. From the shape and size of the melt, the reaction area, $A$, can be calculated $5.5 \mathrm{~cm}^{2}$ by rotating ellipsoid approximation. The volume of the silicon melt may be estimated as $2.4 \mathrm{~cm}^{3}$ from $5.5 \mathrm{~g}$ of the sample weight and $2.33 \mathrm{~g} / \mathrm{cm}^{3}$ of the density of silicon. The value of $A / V$, therefore, is $2.3 \mathrm{~cm}^{-1}$ in this experiment, so that $k_{m}$ is $1.3 \times 10^{-5} \mathrm{~m} / \mathrm{s}$. This seems to be rather small as a value of $k_{m}$ in spite of strong agitation of the melts by impinging plasma jet, leading to the following discussion.

In the above calculation, the boron reaction was assumed to occur over the whole silicon area. However, this reaction may be limited to only at the area where plasma gas is impinging. In other words, only the activated oxygen may react with boron in silicon. The plasma-impinging area is estimated to be $0.50 \mathrm{~cm}^{2}$ assuming that the diameter is equal to that of the nozzle of the plasma torch, $0.8 \mathrm{~cm}$.

Then the above $k_{m}$ value would be modified to be $1.4 \times 10^{-4} \mathrm{~m} / \mathrm{s}$, which is reasonable for the order of mass transfer coefficient under the present experimental conditions. Aratani, who is one of coauthors of Ref. 6), observed that $k_{m}$ defined by Eq. (4) is inversely proportional to the square of crucible diameter under the same conditions and obtained $1.3 \times 10^{-4} \mathrm{~m} / \mathrm{s}$, if the plasma-impinging area was used for estimation, which is in excellent agreement with our modified value. These findings strongly indicate that boron in silicon reacts with gas only at the plasma-impinging area.

\subsection{Effect of the Initial Concentration of Boron on Its Removal}

Figure 6 shows the effect of initial concentration of boron on its behavior as $\ln \left\{[\mathrm{B}] /[\mathrm{B}]_{0}\right\}$ vs. $t$ together with the plots in Fig. 5. Linear relationships are seen between $\ln \left\{[\mathrm{B}] /[\mathrm{B}]_{0}\right\}$ and $t$ for all different initial concentrations of boron, but the slopes of straight lines, i.e. apparent rate constants, depend on the initial concentration of boron. The values of apparent rate constants decrease with decreasing initial concentration of boron. Using the value of the slopes in Fig. $6,1.0 \times 10^{-4}$ and $7.4 \times 10^{-5} \mathrm{~m} / \mathrm{s}$ of $k_{m}$ were obtained for 15 and 5 ppmw of initial boron concentrations, respectively, considering only the plas-

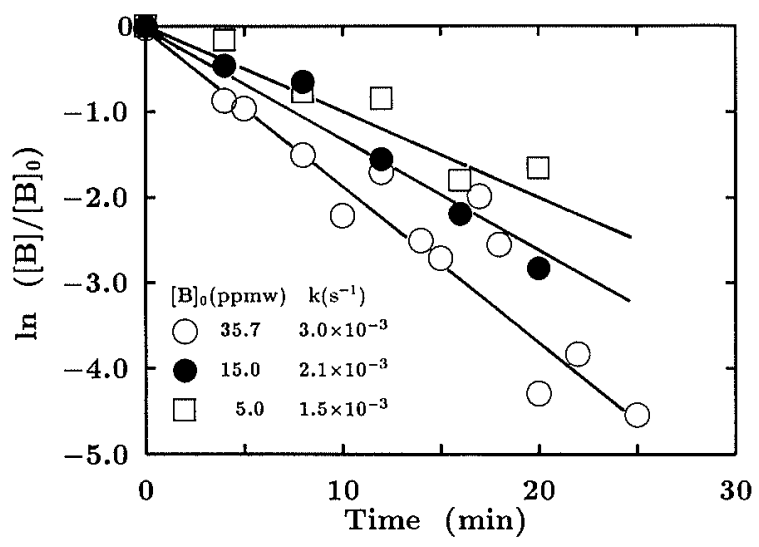

Fig. 6. Relation between $\ln \left([\mathrm{B}] /[\mathrm{B}]_{0}\right)$ and melting time for boron elimination with $\mathrm{Ar}+1.24 \mathrm{vol}_{0} \mathrm{H}_{2} \mathrm{O}$ plasma gas with boron content ranging from 5 to 35.7 ppmw. ma-impinging area. Moreover, the lowest boron level after $20 \mathrm{~min}$ of melting time was 0.5 to $0.9 \mathrm{ppmw}$ independent of the initial concentration of boron. Accordingly, it was found that lowering initial concentration of boron gave no favorable effects on the removing behavior of boron. The reason for these experimental findings is not clear at the moment and should be studied further. There could be the possibility that boron reacts partially with gas even outside the plasma-impinging area when the boron level is relatively high.

Figure 7 shows the relationship between rate of silicon loss and melting time. The loss of silicon increased in proportion to melting time independent of the initial concentration of boron. Namely, it is controlled only by oxygen content of plasma gas. About $0.4 \% /(\mathrm{min} \cdot \mathrm{vol} \%$ $\mathrm{H}_{2} \mathrm{O}$ ) was obtained as the rate of silicon loss per unit time and per unit percentage of $\mathrm{H}_{2} \mathrm{O}$ from the slope in Fig. 7.

\subsection{Effect of Kind of Oxidizing Gas for Plasma}

It has been described earlier that an $\mathrm{Ar} / \mathrm{H}_{2} \mathrm{O}$ mixture is more effective than an $\mathrm{Ar} / \mathrm{O}_{2}$ or $\mathrm{Ar} / \mathrm{CO}_{2}$ for the removal of boron. An experiment using $\mathrm{Ar}+0.44 \mathrm{vol} \%$ $\mathrm{H}_{2} \mathrm{O}+0.44 \mathrm{vol} \% \mathrm{CO}_{2}$ plasma was carried out to investigate the effect of coexistence of $\mathrm{H}_{2} \mathrm{O}$ and $\mathrm{CO}_{2}$ on boron

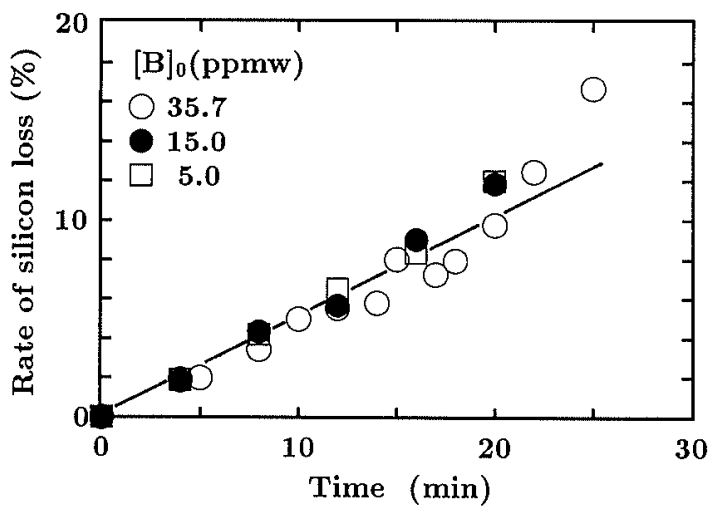

Fig. 7. Relation between the rate of silicon loss and melting time with $\mathrm{Ar}+1.24 \mathrm{vol}_{0} \mathrm{H}_{2} \mathrm{O}$ plasma gas with boron content ranging from 5 to 35.7 ppmw.

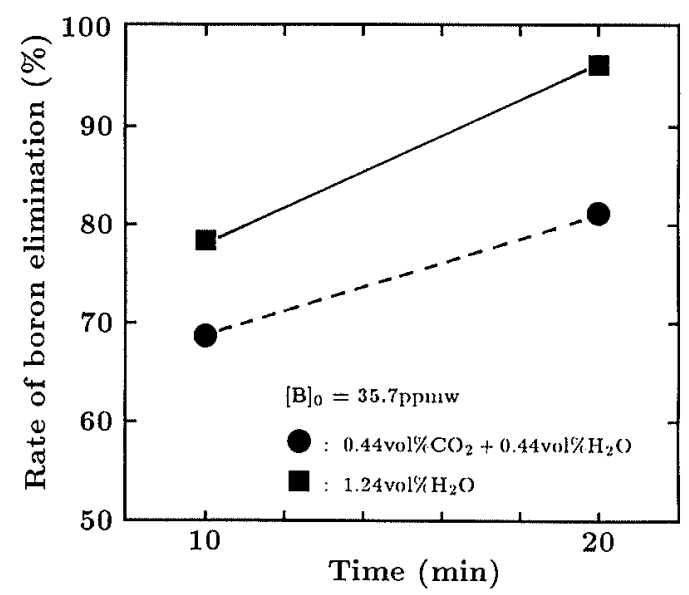

Fig. 8. Comparison of $\mathrm{Ar}+1.24 \mathrm{vol}_{2} \mathrm{H}_{2} \mathrm{O}$ plasma with $\mathrm{Ar}+0.44 \mathrm{vol} \% \mathrm{H}_{2}+0.44 \mathrm{vol} \% \mathrm{CO}_{2}$ plasma with regard to the rate of boron elimination in 10 and $20 \mathrm{~min}$ of melting time. 


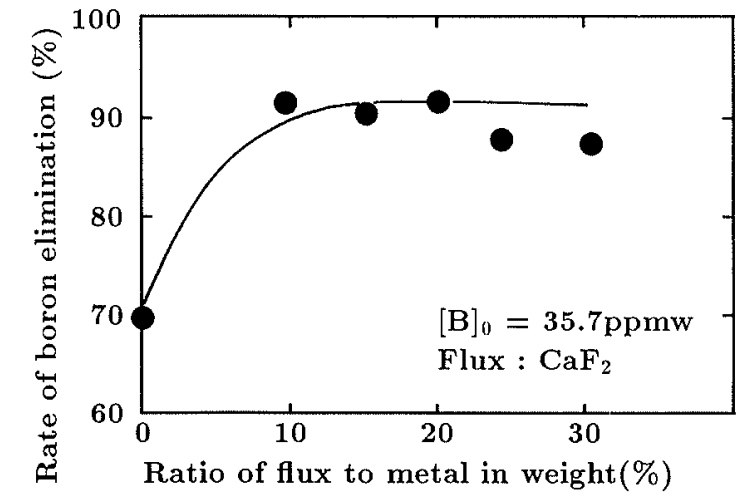

Fig. 9. Dependence of the rate of boron elimination with $\mathrm{Ar}+1.24 \mathrm{vol} \% \mathrm{H}_{2} \mathrm{O}$ plasma gas on relative flux addition to $\mathrm{MG}-\mathrm{Si}$.

elimination, keeping the same oxygen content of plasma gas as $\mathrm{Ar}+1.24 \mathrm{vol} \% \mathrm{H}_{2} \mathrm{O}$. For comparison, the melting time was fixed at 10 and $20 \mathrm{~min}$. As is seen in Fig. 8, the rate of boron elimination with $\mathrm{Ar}+1.24 \mathrm{vol} \% \mathrm{H}_{2} \mathrm{O}$ plasma is 10 to $15 \%$ larger than that with $\mathrm{Ar}+0.44 \mathrm{vol} \%$ $\mathrm{H}_{2} \mathrm{O}+0.44 \mathrm{vol} \% \mathrm{CO}_{2}$ plasma for both melting times.

The reason for this difference may be discussed in terms of the formation of $\mathrm{SiO}_{2}$ film, as stated earlier in $\mathrm{Sec}$. 4.1. When $\mathrm{H}_{2} \mathrm{O}$ is mixed in a plasma working gas, $\mathrm{H}_{2} \mathrm{O}$ will be dissociated at least to $\mathrm{H}$ and $\mathrm{O}$, while $\mathrm{CO}_{2}$ is to $\mathrm{CO}$ and $\mathrm{O}$. This unstable $\mathrm{H}$ or $\mathrm{CO}$ may react with possibly formed $\mathrm{SiO}_{2}$ to form gaseous $\mathrm{SiO}$ before recombination, cleaning the plasma impinging area of molten silicon.

The $\mathrm{SiO}$ vapor pressure for Eq. (5) at $2273 \mathrm{~K}$, which is the observed highest temperature, with $1.24 \mathrm{vol} \%$ of water vapor content is estimated to be $1.63 \times 10^{4} \mathrm{~Pa}$.

$$
\begin{aligned}
& \mathrm{SiO}_{2}(\mathrm{l})+2 \mathrm{H}(\mathrm{g})=\mathrm{SiO}(\mathrm{g})+\mathrm{H}_{2} \mathrm{O}(\mathrm{g}) \\
& \Delta G^{\circ}=-70.6 \mathrm{~kJ} / \mathrm{mol} \quad \text { at } 2273 \mathrm{~K}
\end{aligned}
$$

assuming $P_{\mathrm{H}_{2} \mathrm{O}}=P_{\mathrm{SiO}}$ and $P_{\mathrm{H}}=2 P_{\mathrm{H}_{2}}=2 \times 1.24 \times 10^{-2} \times$ $1.013 \times 10^{5}=2.51 \times 10^{3} \mathrm{~Pa}$.

Similarly, $P_{\text {Sio }}$ for the same $\mathrm{CO}_{2}$ content of the $\mathrm{Ar} / \mathrm{CO}_{2}$ mixture is $2.63 \times 10^{2} \mathrm{~Pa}$, which is lower than the value for $\mathrm{Ar} / \mathrm{H}_{2} \mathrm{O}, 1.63 \times 10^{4} \mathrm{~Pa}$, by a factor of approximately 62. In other words, it is presumed that with $\mathrm{Ar} / \mathrm{H}_{2} \mathrm{O}$ the plasma-impinging area, where gaseous boron oxide is likely to form, would be less contaminated by $\mathrm{SiO}_{2}$ than in the case of $\mathrm{Ar} / \mathrm{CO}_{2}$ mixture, giving a more favorable condition for boron removal although it is not clear which is more important, excited oxygen species or enhanced mass transfer. This is consistent with the present observations described in the foregoing. Consequently, it is clear that $\mathrm{Ar} / \mathrm{H}_{2} \mathrm{O}$ mixture is more effective than $\mathrm{Ar}+\mathrm{H}_{2} \mathrm{O}+\mathrm{CO}_{2}$ mixture for the removal of boron.

\subsection{Effect of Addition of Flux on the Removal of Boron}

Figure 9 shows the relationship between boron elimination and percentage of $\mathrm{CaF}_{2}$ in weight added to silicon melt during the first $10 \mathrm{~min}$ using $\mathrm{Ar}+1.1 \mathrm{vol} \%$ $\mathrm{H}_{2} \mathrm{O}$ plasma. It was found that the percentage of elimination of boron increased by about $20 \%$ by the addition of $\mathrm{CaF}_{2}$ up to $10 \%$, while an amount of silicon loss did not change.

This improvement may be due to the formation of gaseous $\mathrm{BF}_{3}$ following the reaction; $3 / 2\left(\mathrm{CaF}_{2}\right)+1 / 2$ $\left(\mathrm{B}_{2} \mathrm{O}_{3}\right)=3 / 2(\mathrm{CaO})+\mathrm{BF}_{3}(\mathrm{~g})$, as indicated by Fedko et al. ${ }^{7)}$ or BOF by Humbert et al. ${ }^{8)}$ but it must be proved in the future.

\section{Conclusions}

The removal of boron from MG-Si has been investigated by using $\mathrm{Ar} / \mathrm{H}_{2} \mathrm{O}$ plasma to develop a lowcost SOG-Si. From a series of the experiments the following information was obtained:

(1) Boron in the MG-Si was reduced from 35.7 to $0.4 \mathrm{ppmw}$, which is low enough for SOG-Si, using $\mathrm{Ar}+1.24 \mathrm{vol} \% \mathrm{H}_{2} \mathrm{O}$ plasma.

(2) Kinetic analyses have been carried out using the data with $\mathrm{Ar}+1.24 \mathrm{vol} \% \mathrm{H}_{2} \mathrm{O}$ plasma. It was found that the rate of removal of boron is controlled by the diffusion of boron in the silicon melt. The mass transfer coefficient was evaluated to be $1.4 \times 10^{-4} \mathrm{~m} / \mathrm{s}$, considering the plasma-impinging area. In addition, it was found that the rate of silicon loss increased in proportion to melting time. The value of $0.4 \% /\left(\mathrm{min} \cdot \mathrm{vol} \% \mathrm{H}_{2} \mathrm{O}\right)$ was obtained as the rate of silicon loss per unit melting time and per unit percentage of $\mathrm{H}_{2} \mathrm{O}$.

(3) Among weakly oxidizing plasma treatments for the removal of boron, the largest removal was obtained when using an $\mathrm{Ar} / \mathrm{H}_{2} \mathrm{O}$ operating gas, which is also effective to keep silicon loss at a low level, probably because the plasma-impinging area is kept clean.

(4) About $20 \%$ of enhancement of boron elimination was observed by adding $\mathrm{CaF}_{2}$ up to $10 \%$.

\section{Acknowledgment}

The authors thank Professor C. Finn, Northeasten University, for his help in preparing the manuscript.

\section{REFERENCES}

1) J. Dietl: Proc. 8th E.C. Photovoltaic Solar Energy Conf., Vol. 1, Kluwer Academic Publishers, Dordrecht, The Netherlands, (1988), 599.

2) K. Suzuki, K. Sakaguchi, T. Nakagiri and N. Sano: J. Jpn. Inst. Met., 54 (1990), 161

3) K. Suzuki, T. Sugiyama, K. Takano and N. Sano: J. Jpn. Inst Met., 54 (1990), 168

4) H. C. Theuerer: J. Met., 6 (1956), 1316.

5) J. Amouroux, F. Slootman, N. Madigou, T. Rogen and D. Morvan: Proc. 8th Int. Symp. Plasma Chemistry, Vol. 3, Tokyo, (1987), 1868.

6) H. Baba, N. Yuge, Y. Sakaguchi, F. Aratani and Y. Habu: Proc. IOth E.C. Photovoltaic Solar Energy Conf., Kluwer Academic Publishers, Dordrecht, The Netherlands, (1991), 286.

7) J. Fedko and M. Krucinski: Ironmaking Steelmaking, 16 (1989), 116.

8) P. Humbert, R. Combes, J. Erin, D. Morvan and J. Amouroux: Proc. 10th E.C. Photovoltaic Solar Energy Conf., Kluwer Academic Publishers, Dordrecht, The Netherlands, (1991), 261 . 